\title{
THE REGULATION OF NEUTRAL AMINO ACID TRANSPORT IN MAMMALIAN CELLS
}

\author{
MARK A. SHOTWELL ${ }^{a}$, MICHAEL S. KILBERG ${ }^{b}$ and DALE L. OXENDER ${ }^{\text {a,* }}$ \\ "Department of Biological Chemistry, University of Michigan, Ann Arbor, MI 48109 and ${ }^{b}$ Department of Biochemistry and Molecular \\ Biology, University of Florida, Gainesville, FL 32610 (U.S.A.)
}

(Received October 6th, 1982)

\section{Contents}

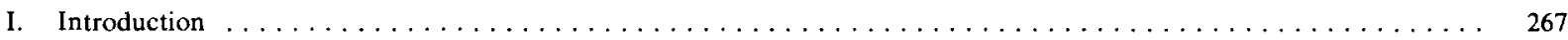

II. Characterization of neutral amino acid transport systems in animal cells $\ldots \ldots \ldots \ldots$

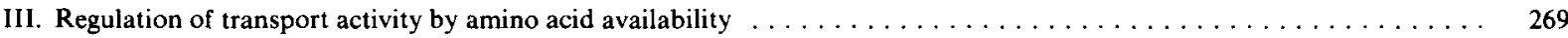

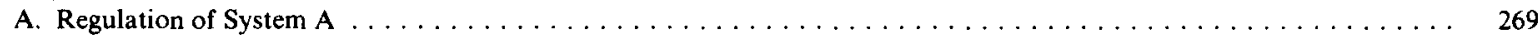

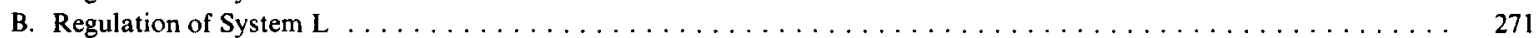

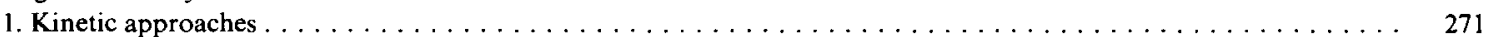

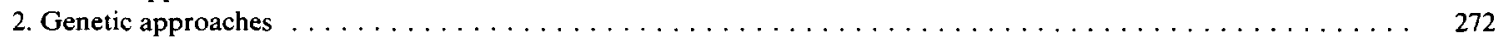

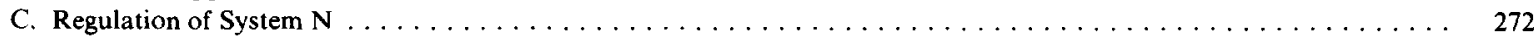

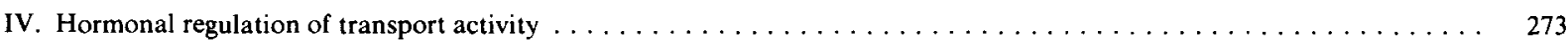

A. Effect of down regulation on hormone-stimulated amino acid transport $\ldots \ldots \ldots \ldots \ldots$

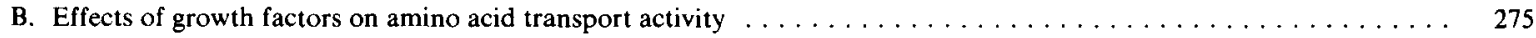

C. Role of cyclic AMP and calcium ion in the hormonal regulation of amino acid transport $\ldots \ldots \ldots . \ldots 276$

D. Effects of hormones on the kinetics of amino acid transport $\ldots \ldots \ldots \ldots \ldots \ldots$

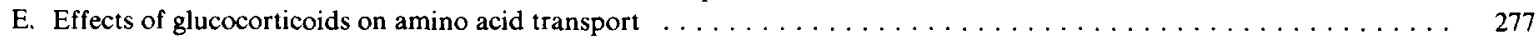

F. Possible mechanisms of the hormonal stimulation of amino acid transport $\ldots \ldots \ldots \ldots$

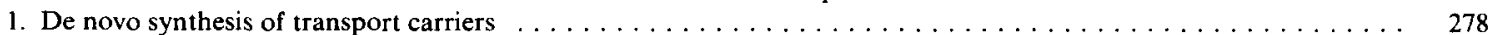

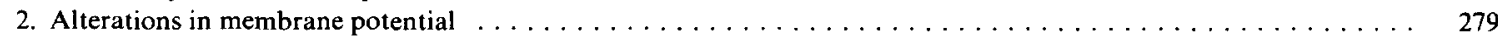

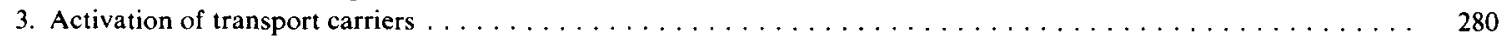

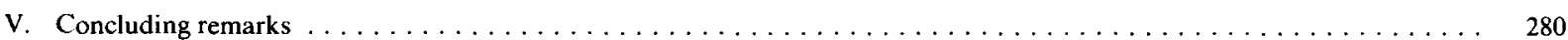

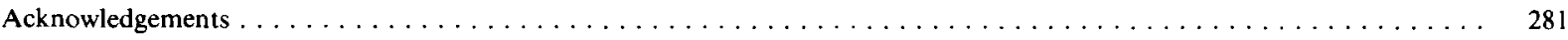

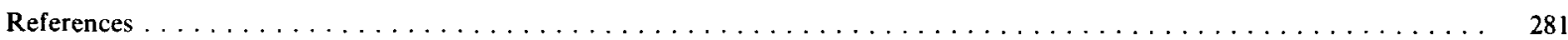

\section{Introduction}

In animal cells as well as in microorganisms the intracellular levels of most amino acids are regu-

* To whom correspondence should be addressed. Abbreviations: AIB, 2 aminoisobutyric acid; MeAIB, 2-methylaminoisobutyric acid; $\mathrm{BCH}, 2$-aminobicyclo-[2,2,1]-heptane-2carboxylic acid; $\mathrm{CHO}$, Chinese hamster ovary. lated to meet $t$ utritional requirements of the cells. The amir acid levels are maintained by balancing the uptake of amino acids from the extracellular medium, and the biosynthesis of certain of the amino acids, with the needs of the cell for amino acids for protein synthesis and energy metabolism. The uptake of the neutral amino acids in animal tissues is carried out by several distinct 
transport systems, which differ in their reactivities with substrates, ions, and inhibitors. Although the transport systems have been examined kinetically in a great many tissues and cell types, only fairly recently have these studies included the characterization of the regulation of transport. Transport activity in animal cells has been shown to be affected, for example, by the cell density [1-4], the position in the cell cycle [4], and viral transformation $[1,3,5]$. In this article, however, we will consider first the characterization of the neutral amino acid transport systems in mammalian cells, and then review some of the recent research on the regulation of the activities of these transport systems by nutrient availability and hormones.

\section{Characterization of neutral amino acid transport systems in animal cells}

The uptake of neutral amino acids by animal cells is divided among a few transport systems that have overlapping substrate reactivities. Largely on the basis of the pattern of competitive interactions between neutral amino acids, Oxender and Christensen [6] proposed the existence of two distinct routes of amino acid uptake in the Ehrlich ascites tumor cell. These were termed transport System A and transport System L.

System $\mathrm{A}$ is most reactive with amino acids having short, polar, or linear side chains, such as alanine, glycine, and the nonmetabolizable analog 2-aminoisobutyric acid (AIB) and its $N$-methylated derivative, 2-methylaminoisobutyric acid (MeAIB). Transport by System A is sodium iondependent and is greatly reduced at lowered extracellular $\mathrm{pH}$. Uptake of amino acids by System $A$ is often subject to trans-inhibition by intracellular substrates of this system. System $L$ is most reactive with branched-chain and aromatic amino acids, such as leucine, isoleucine, valine, phenylalanine, and the nonmetabolizable analog 2aminobicyclo-[2,2,1]-heptane-2-carboxylic acid (BCH). Transport by System $L$ is sodium ion-independent and in some cases is even stimulated by lowered extracellular pH. Uptake by System L is trans-stimulated by intracellular substrates of this system. Amino acid transport systems corresponding to Systems $A$ and $L$ have been described in a wide variety of animal cell types, including cells of avian and mammalian origin (for a listing, see Ref. 7).

A second sodium-dependent transport system was later characterized in the Ehrlich cell [8]. This system, which was more or less restricted in reactivity to alanine, serine, and cysteine, was termed System ASC. In addition to its substrate preference, System ASC is distinguished from System A on the basis of its relative $\mathrm{pH}$-insensitivity, higher stereospecificity, intolerance of $N$-methylated substrates, and ability to be trans-stimulated by intracellular amino acids. Although it is a minor component in the Ehrlich cell, System ASC was shown to be a prominent system in the rabbit reticulocyte [9] and pigeon erythrocyte [10], cells in which System A activity is difficult to evaluate. System ASC is also more prominent and has a broader substrate reactivity in the rat hepatocyte [11], cultured human fibroblast [12,13], and Chinese hamster ovary cell $[14,15]$.

There have been reports of additional sodiumdependent neutral amino acid transport systems that are apparently present in only one or a few cell types and often have a narrow range of substrates. System Gly, specific for glycine and its $N$-methylated derivative, sarcosine, was first described in the pigeon erythrocyte $[16,17]$ and rabbit reticulocyte [10]. More recently it was detected in rat hepatocytes and the hepatoma cell line HTC [18]. Christensen [19] has suggested that System Gly is a variant of System A.

A transport route serving for the uptake of $\beta$-amino acids has been characterized in the Ehrlich cell $[20,21]$ and is also known to occur in other eukaryotic cells. Taurine, a slowly metabolized, naturally occuring $\beta$-amino acid, has served as an appropriate model substrate of this system. This system is sodium-dependent and has been termed System $\beta$ [21].

Recently a sodium-dependent transport system restricted in reactivity to glutamine, aspargine, histidine, and a few synthetic analogs was described in cultured rat hepatocytes [22,23]. This uptake route was named System $\mathrm{N}$ for the nitrogen-containing side chains of each of its substrates. In addition to its specificity, System $\mathrm{N}$ was distinguished from System $\mathrm{A}$ on the basis of its insensitivity to insulin and glucagon, and from System ASC on the basis of its increased activity 
following amino acid starvation [22]. System N activity has been shown to occur in fetal hepatocytes and the hepatoma cell line H4-II-EC3 (Vadgama, J.V. and Christensen, H.N., unpublished data), but not in Chinese hamster ovary cells (Shotwell, M.S. and Oxender, D.L., unpublished data), human fibroblasts, or rat intestinal segments (Kilberg, M.S., unpublished data). These results have led to the suggestion that System $N$ is unique to the liver [24].

Consideration of the common structural features of preferred substrates of Systems A and L led Christensen to design and synthesize amino acid analogs that are not metabolized by eukaryotic cells and are restricted in entry as much as possible to a single transport system. The analog MeAIB has been used as a System A-specific substrate [25], and the analog $\mathrm{BCH}$ has been similarly employed for System L [26]. These two relatively system-specific model amino acids have been used as competitive inhibitors to discriminate among transport routes. The component of uptake of an amino acid that is sensitive to inhibition by excess MeAIB can be assigned to System $A$, and the $\mathrm{BCH}$-inhibitable portion of uptake can be assigned to System L. Christensen has thoroughly discussed the synthesis of these and other systemspecific amino acid analogs [19,27]. AIB has often been used as a model substrate for System A, but because the uptake of AIB occurs by multiple transport systems in several cell types $[14,15$, 28-32], it should not be identified solely with System A, unless that relation has been proved for a particular cell type.

A persistent problem in the discrimination of transport systems by inhibition analysis has been in finding an appropriate model amino acid for System ASC. Cysteine appears to serve as a specific substrate in the rat hepatocyte [28], and threonine may serve as an appropriate substrate in HTC cells [29], but the lack of an acceptable model substrate for System ASC in other cell types complicates the characterization of this system in the presence of other neutral amino acid transport systems. In some cases, System ASC activity has been operationally defined as the sodium-dependent uptake of an amino acid that is not inhibited by excess MeAIB [14,15] or $N$-methylalanine [33], although kinetic criteria of identification have also been applied [13]. More extensive discussions of the difficulty in distinguishing System ASC from System A have recently been reported [13,30].

Table $I$ is a summary of the characteristics of the neutral amino acid transport systems in animal cells.

\section{Regulation of transport activity by amino acid availability}

\section{IIIA. Regulation of System A}

Animal cells adapt to changes in nutrient availability by regulating the activities of their amino acid transport systems. Riggs and Pan [34], using immature rat uterus preparations, and Guidotti and co-workers [35], using chick embryo heart cells, first observed that incubation of certain tissues in amino acid-free medium for 3 to $5 \mathrm{~h}$ led to increased neutral amino acid transport. This response has been referred to as adaptive regulation or starvation-induced transport enhancement. The increased transport activity was identified with System A on the basis of its sodium ion dependence, $\mathrm{pH}$ sensitivity, and by inhibition analysis $[34,36]$. Several studies have shown that Systems ASC and $L$ are not increased in activity by incubation in amino acid-free medium [36-39]. The addition of System $A$ amino acids to the medium prevented the enhancement of System A activity, but typical substrates of System L did not [35]. Individual amino acids could suppress the System A transport, and AIB was particularily effective $[35,36]$. The starvation-induced transport was accompanied by an increase in the $V_{\max }$ of uptake of amino acids by System A with no significant change in the $K_{\mathrm{m}}$ of uptake $[34,35,40]$. These results are consistent with an increase in the number of active System A transport carriers. Because the increased transport activity could still be observed in cells depleted of amino acids prior to uptake measurements, release from trans-inhibition was ruled out as a basis for the adaptive response to amino acid deprivation [35].

An examination of the relationship between amino acid transport and the supply of amino acids showed that System A activity varies inversely with the concentration of System A amino acids in the culture medium [41]. Higher levels of 
TABLE I

CHARACTERISTICS OF THE NEUTRAL AMINO ACID TRANSPORT SYSTEMS IN ANIMAL CELLS

\begin{tabular}{|c|c|c|c|c|c|c|}
\hline & A & $\mathrm{ASC}$ & Gly & $\beta$ & $\mathrm{N}$ & $\mathbf{L}$ \\
\hline 1.Cation-dependence & $\begin{array}{l}\text { sodium- } \\
\text { dependent }\end{array}$ & $\begin{array}{l}\text { sodium- } \\
\text { dependent }\end{array}$ & $\begin{array}{l}\text { sodium- } \\
\text { dependent }\end{array}$ & $\begin{array}{l}\text { sodium- } \\
\text { dependent }\end{array}$ & $\begin{array}{l}\text { sodium- } \\
\text { dependent }\end{array}$ & $\begin{array}{l}\text { sodium- } \\
\text { independent }\end{array}$ \\
\hline 2.Substrate reactivity & $\begin{array}{l}\text { most, esp. } \\
\text { Ala, Gly, } \\
\text { Pro, AIB }\end{array}$ & $\begin{array}{l}\text { Ala, Ser, } \\
\text { Cys }\end{array}$ & $\begin{array}{l}\text { Gly, sar- } \\
\text { cosine }\end{array}$ & $\begin{array}{l}\beta-\mathrm{Ala} \\
\text { taurine }\end{array}$ & $\begin{array}{l}\text { Asn, Gln, } \\
\text { His }\end{array}$ & $\begin{array}{l}\text { most, esp. } \\
\text { Leu, Ile, } \\
\text { Val, Phe }\end{array}$ \\
\hline 3.Specific substrate & MeAIB & Cys, Thr ${ }^{b}$ & Gly & taurine & Gln & $\mathrm{BCH}$ \\
\hline 4.Trans Effects & $\begin{array}{l}\text { trans - } \\
\text { inhibited }\end{array}$ & $\begin{array}{l}\text { trans - } \\
\text { stimulated }\end{array}$ & $?$ & $?$ & $?$ & $\begin{array}{l}\text { trans - } \\
\text { stimulated }\end{array}$ \\
\hline 5. Effect of low $\mathrm{pH}$ & inhibited & variable ${ }^{c}$ & none & $?$ & inhibited & stimulated \\
\hline 6.Stereospecificity & moderate & high & - & $?$ & high & moderate \\
\hline $\begin{array}{l}\text { 7. Regulation by amino acid limita- } \\
\text { tion }\end{array}$ & yes & no & no & no & yes & yes ${ }^{d}$ \\
\hline 8.Hormonal regulation & yes & no & no & no & no & no \\
\hline 9.Cell in which first described & EATC $^{e}$ & EATC & $\begin{array}{l}\text { pigeon } \\
\text { erythrocyte }\end{array}$ & EATC & $\begin{array}{l}\text { rat hepat- } \\
\text { ocyte }\end{array}$ & EATC \\
\hline 10.Cell distribution & $\begin{array}{l}\text { most, not } \\
\text { erythrocyte, } \\
\text { reticulocyte }\end{array}$ & ubiquitous? & $\begin{array}{l}\text { pigeon } \\
\text { erythrocyte, } \\
\text { rabbit } \\
\text { reticulocyte, } \\
\text { HTC }\end{array}$ & $\begin{array}{l}\text { EATC, rat } \\
\text { hepatocyte }\end{array}$ & $\begin{array}{l}\text { rat hepat- } \\
\text { ocyte }\end{array}$ & ubiquitous? \\
\hline
\end{tabular}

a Broader substrate reactivity (including Thr, Leu, Ile, and Phe) in rabbit ileum [57], Chinese hamster ovary cells [14,15], and rat hepatocytes [30].

b Cys in rat hepatocytes and intestinal epithelium [28], Thr in HTC cells [29], and both in H4-II-EC3 cell (Vadgama, J.V. and Christensen, H.N., unpublished data).

c Inhibited below pH 6.0 in HTC cells [29]; not inhibited in hepatocytes [22].

d Enhanced activity caused by leucine limitation in Chinese hamster ovary cells [52,53]; inverse changes in activity in two sodium-independent components, Systems L1 and L2, in primary cultures of rat hepatocytes [54,55].

' EATC, Ehrlich ascites tumor cell.

substrates of System A in the growth medium thus lead to lower System A activities.

The regulation of System A transport activity by amino acid supply has now been described in many tissue and cell types [7,37,42-47] including cells in culture $[14,38,39,41,48,49]$.

The enhancement in System A activity by starvation for amino acids apparently requires synthesis of both RNA and protein. Inhibitors both of transcription and translation have been shown to prevent this response in several cell types $[14,34,35,38,39,43,45,50,51]$. Guidotti and coworkers [50] showed that actinomycin D was ineffective in preventing the increase in transport when added after $90 \mathrm{~min}$ of starvation, and suggested that increased transcription occurs within $30 \mathrm{~min}$ of starvation. In contrast, addition of the protein synthesis inhibitor cycloheximide at times past 90 min blocked any further increase in transport [50]. Guidotti and colleagues have concluded from their studies using inhibitors of macromolecular synthesis that System A transport activity is regulated by a repression-derepression mechanism acting at the transcriptional level $[7,50,51]$.

The reversal of the starvation-induced System A enhancement by refeeding with amino acids was also found to require active RNA and protein synthesis in both chick embryo fibroblasts [51] and cultured human fibroblasts [50]. In the presence of a protein synthesis inhibitor, the half-life of enhanced System A transport was found to be about $200 \mathrm{~min}$ in chick embryo fibroblasts [51] and several hours in cultured human fibroblasts [50]. In both cell types the decay of the uptake to basal levels was accelerated by the addition of System A amino acids. These observations led Guidotti to 
propose a complex model involving a factor that degrades or inactivates System A activity following refeeding of starved cells with System A amino acids [50,51].

\section{IIIB. Regulation of System L}

\section{IIIB-1. Kinetic approaches}

System L transport activity is also regulated in animal cells. Many of the early studies using several cell types showed that, in contrast to System A, System L is either unchanged or slightly decreased in activity following complete starvation for amino acids [36-39]. Adaptive increases in System L transport can, however, be easily observed in a temperature-sensitive leucyl-tRNA synthetase Chinese hamster ovary mutant, the CHO-ts $\mathrm{Hl}$ line, when these cells are grown at marginally permissive temperatures [52,53], and also in primary cultures of rat hepatocytes [54,55].

The CHO-ts $\mathrm{Hl}$ mutant cell line has a temperature-sensitive leucyl-tRNA synthetase and grows normally at $34^{\circ} \mathrm{C}$, but cannot grow at $39^{\circ} \mathrm{C}$. When $\mathrm{CHO}-t s \mathrm{Hl}$ cells are incubated at $38^{\circ} \mathrm{C}$, a temperature at which the leucyl-tRNA synthetase is partially inactivated, the transport activity for leucine increases two- to threefold [52,53]. This temperature-dependent increase in leucine transport was shown to be restricted to System L on the basis of its sodium independence, substrate reactivity, and inhibition by $\mathrm{BCH}$ [53]. This transport enhancement is reflected by an increase in the $V_{\max }$ of leucine uptake with no change in its $K_{\mathrm{m}}$ of uptake [53]. These results are consistent with an increase in the number of System L transport carriers.

The temperature-dependent elevation in System $\mathrm{L}$ activity in CHO-ts $\mathrm{H} 1$ cells could not be explained by a trans-stimulation of System L by intracellular amino acids because cells depleted of amino acids prior to uptake measurements still showed increased transport [53]. The transport enhancement could be prevented by cycloheximide but not by actinomycin $\mathrm{D}$, leading to the suggestion that System L may be regulated at the translational level [53].

Increases in System L activity were also observed in nonmutant $\mathrm{CHO}$ cells, although it was necessary to incubate the cells in media containing very low concentrations of leucine and normal levels of all other nutrients [53]. It was concluded that starving $\mathrm{CHO}$ cells for leucine, whether by incubating a temperature-sensitive leucyl-tRNA synthetase mutant at an elevated temperature, or by incubating nonmutant cells in very low levels of leucine, leads to increased amino acid transport activity by System $L$. The regulation of the activity of transport System L appears, therefore, to be linked to the availability of leucine for protein synthesis, and conceivably the signal for this leucine-dependent regulation may be the ratio of charged to uncharged tRNA ${ }^{\mathrm{Leu}}$, rather than simply the size of the intracellular pool of leucine.

Although the adaptive regulation of System A and the leucine-dependent regulation of System $\mathrm{L}$ in animal cells are both adaptive responses leading to an increase in the activity of a single amino acid transport system, significant differences exist between the two. First, System A derepression can be observed only after limitation of all of the System A amino acids, whereas System $L$ is not elevated under these conditions. System $L$ enhancements result from the deprivation of but a single System $\mathrm{L}$ amino acid, leucine. Second, the maximum increase in System A activity occurs much more slowly than that for System L. Whereas System A activity rises for 12 to $20 \mathrm{~h}$ of amino acid starvation [39,41], System L transport increases occur within the first $4 \mathrm{~h}$ of leucine limitation [53]. A third distinction is that the increased activity of System A is slowly reversed upon amino acid refeeding. This reversal requires 6 to $12 \mathrm{~h}[38,50]$, whereas the reversal of enhancement in System L activity is complete within $6 \mathrm{~h}$ after shifting CHO$t s \mathrm{H} \mathbf{l}$ cells from an elevated temperature back to a permissive temperature [53]. A final contrast is that whereas the derepression of System $A$ is prevented by inhibitors both of transcription and translation $[14,35,38,39,43,45,50,51]$, the System L enhancement in CHO-ts $\mathrm{Hl}$ cells is not dependent upon active RNA synthesis for the first $4 \mathrm{~h}$ [53]. Accordingly, it has been tentatively suggested that different sites of control exist for the two systems. System A may be regulated at the level of transcription [7,50] and System $L$ at the level of translation [53].

Kinetic heterogeneity has been demonstrated for sodium-independent transport of $\mathrm{BCH}$, histidine, leucine, and tryptophan in primary cultures 
of rat hepatocytes [54,55]. On the basis of this kinetic analysis, inhibition analysis, and other criteria, it was concluded that there are at least two sodium-independent systems for neutral amino acid transport in cultured hepatocytes. These components, designated L1 and L2, exhibit marked changes in activity during the first $48 \mathrm{~h}$ after establishment of primary cultures [55]. The System $\mathrm{L} 1$ activity, characterized by $K_{\mathrm{m}}$ values in the micromolar range, was almost undetectable in freshly isolated hepatocytes or in cells cultured for less than $6 \mathrm{~h}$ [55]. This activity increased significantly during the next 48 hours and continued to increase for at least 6 days. In contrast, uptake by System L2 was quite rapid in freshly isolated cells, but its activity declined during the first $48 \mathrm{~h}$ of culturing such that transport by System L1 predominated. System L2 exhibits $K_{\mathrm{m}}$ values in the millimolar range, and the decrease in activity is the result of a lowering of the $V_{\max }[54,55]$. The factors controlling these changes in sodium-independent transport are not yet known, but the increase in System $\mathrm{Ll}$ activity is dependent on both RNA and protein synthesis. Furthermore, cell density may affect the rate at which these changes occur (Kilberg, M.S., unpublished data).

\section{IIIB-2. Genetic approaches}

Recently temperature-resistant revertants were isolated from the $\mathrm{CHO}-t s \mathrm{Hl}$ cell line that appear to be defective in the regulation of the activity of System $\mathrm{L}$. These revertants grow normally at $39^{\circ} \mathrm{C}$ in reduced leucine medium, conditions lethal for the temperature-sensitive starting strain, CHO$t s \mathrm{H} 1$. The revertants were found to have two- to threefold increased System L activity even when grown at $34^{\circ} \mathrm{C}$. It was suggested that this constitutively high transport activity resulted from a mutational defect in the regulation of System $L$ expression in each revertant cell line (Shotwell, M.A., Collarini, E.J., Hampel, A.E. and Oxender, D.L., unpublished data).

In a second genetic approach, another temperature-sensitive leucyl-tRNA synthetase $\mathrm{CHO}$ mutant was fused with a human leukocyte to form interspecific hybrid cells [56]. Temperature-resistant hybrids were then selected for growth at $38.5^{\circ} \mathrm{C}$. In some of these temperature-resistant hamster-human strains the activity of transport
System $\mathrm{L}$ was found to be elevated and to no longer respond to the growth temperature (Lobatón, C.D. and Oxender, D.L., unpublished data). Segregation of human chromosomes from one of these high transport hybrids was then allowed. Karyotype analysis showed a correlation between the high transport phenotype and the presence of a single small human chromosome, which presumably carries a gene for leucine transport (Lobatón, C.D. and Oxender, D.L., unpublished data). Efforts are underway to identify the human chromosome giving high leucine transport.

\section{IIIC. Regulation of System N}

The activity of the recently characterized transport System $\mathbf{N}$ is regulated in cultured rat hepatocytes [22], as well as in the hepatoma cell line H4-II-EC 3 and normal fetal cells (Vadgama, J.V. and Christensen, H.N., unpublished data). The uptake of glutamine, taken as a model System N substrate, was increased about twofold after incubation of cultured hepatocytes in amino acid-free medium for $8 \mathrm{~h}$ [22]. This increased glutamine uptake was only partially inhibited by excess MeAIB, and was attributed therefore to System N instead of System A $[22,23]$. The adaptive increase in glutamine uptake was prevented by the addition to the starvation medium of one System N substrate, histidine, but not of two others, glutamine and asparagine [23]. Paradoxically, increased transport by System $\mathrm{N}$ was also largely eliminated by the addition of AIB, MeAIB, and cysteine, which are all neither substrates nor inhibitors of System N [23]. The protein synthesis inhibitor cycloheximide was also effective in preventing the starvation-induced glutamine transport enhancement in cultured hepatocytes, consistent with a role of protein synthesis in the regulation of System $\mathrm{N}$ activity [23].

Although both are adaptive responses to amino acid deprivation, the starvation-induced enhancement of System $\mathrm{N}$ activity is relatively smaller than that of System A [22]. Nevertheless, even the two- to threefold increases in System $\mathbf{N}$ activity that have been observed would alter the flux of System N substrates considerably. The relevance of System $\mathrm{N}$ regulation to the metabolism of amino acids in the liver has yet to be established, however. 


\section{Hormonal regulation of transport activity}

The regulation of neutral amino acid transport activity reviewed in the preceding sections comprises adaptive responses of individual cells to changes in the availability of nutrient amino acids. Higher organisms require additional regulatory control of amino acid transport in order to adjust nutrient flows between the different cell types in each organ, as well as between the different organs in the body. Control by hormones is one mechanism by which nutrient flows are coordinated in the multi-tissue organism. The hormonal regulation of amino acid metabolism can be divided into three phases: (1) the hormone-induced degradation of protein and mobilization of amino acids; (2) the hormone-stimulated transport of amino acids in target tissues; and, (3) the hormone-regu-

TABLE II

\section{EFFECTS OF HORMONES, GROWTH FACTORS, AND CYCLIC AMP ON AMINO ACID TRANSPORT}

Much of the present information was obtained from previous reviews of this subject $[7,58,59]$. References that appear in this table are for reports not included in these previous reviews, or in some instances are for conflicting results with the same tissue.

\begin{tabular}{|c|c|}
\hline Effector & Observed effect \\
\hline 1. $\mathrm{ACTH}$ & $\begin{array}{l}\text { Increased in adrenal gland, muscle, and intestine } \\
\text { Decreased in kidney and adipose [158] }\end{array}$ \\
\hline 2. Androgens & Increased in prostate gland, seminal vesicles, skeletal muscle, and kidney \\
\hline 3. CAMP & $\begin{array}{l}\text { Increased in liver }[66,157] \text {, thymocytes, bond cells, } 3 \mathrm{~T} 3 \text { cells }[150,159] \text {, and } \\
\text { kidney }[160] \\
\text { Decreased in adipose and kidney [161] }\end{array}$ \\
\hline 4. Catecholamines & $\begin{array}{l}\text { Increased in liver, kidney, heart, muscle, and intestine } \\
\text { Decreased in adipose and muscle }\end{array}$ \\
\hline 5. Epidermal growth factor (EGF) & Increased in chick embryo heart cells [162] and human fibroblasts [93] \\
\hline 6. Estrogens & Increased in uterus and Ehrlich cells \\
\hline 7. Fibroblast growth factor (FGF) & Increased in fibroblasts [94] \\
\hline 8. Follicle stimulating hormone (FSH) & Increased in ovaries and testes \\
\hline 9. Glucagon & Increased in liver \\
\hline & Decreased in adipose [161] \\
\hline 10. Glucocorticoids & $\begin{array}{l}\text { Increased in liver }[115,163] \text { and fibroblasts } \\
\text { Decreased in muscle, thymocytes, lymphocytes, mammary gland, HeLa } \\
\text { cells, JTC- } 4 \text { cells, L-929 cells, diaphragm, hepatomas [119], and normal } \\
\text { liver }[161,164]\end{array}$ \\
\hline 11. Growth hormone & Increased in skeletal muscle, heart, liver [165], diaphragm, and adipose \\
\hline 12. Insulin & $\begin{array}{l}\text { Increased in skeletal muscle, diaphragm, heart, liver, adrenal gland, bone, } \\
\text { lymphocytes, uterus, adipose, fibroblasts, mammary [133], thyroid, retina } \\
\text { [166], mammary adenocarcinoma [167], and lung [168] } \\
\text { Decreased in kidney }\end{array}$ \\
\hline 13. Luteinizing hormone (LH) & Increased in ovaries \\
\hline 14. Multiplication-stimulating activity (MSA) & Increased in chick embryo heart cells and hepatoma cells $[97,98]$ \\
\hline 15. Nerve growth factor (NGF) & Increased in pheochromocytoma cells [96] \\
\hline 16. Parathyroid hormone (PTH) & Increased in bone, calvaria, and kidney cortex \\
\hline 17. Platelet-derived growth factor (PDGF) & Increased in human diploid fibroblasts [95] \\
\hline 18. Prolactin & Increased in intestine and mammary tissue \\
\hline 19. Prostaglandins & Increased in thymocytes and bone \\
\hline 20. Somatomedins & Increased in cartilage, diaphragm, and fibroblasts [170] \\
\hline 21. Thyroid stimulating hormone (TSH) & Increased in skeletal muscle, liver, and thyroid \\
\hline 22. Thyroid hormones & $\begin{array}{l}\text { Increased in bone, cartilage, thymocytes, intestine [171], and liver [172] } \\
\text { Decreased in pituitary }\end{array}$ \\
\hline
\end{tabular}


lated metabolism of the accumulated amino acids. In the following section we will review only the second phase of hormone regulation, the hormonal regulation of amino acid transport across the plasma membrane of mammalian cells.

The effects of several classes of hormones have been reviewed elsewhere [7,24,58,59], and Table II is an updated summary of the hormonal control of amino acid transport. In most instances there is a correlation between the stimulation of amino acid uptake by a hormone in its specific target tissues and an increase in the anabolic activities of the cell, such as macromolecular synthesis, energy production, or cell division. Conversely, transport is either unaffected or inhibited when the effect of the hormone is catabolic, as in the case of glucocorticoid inhibition of amino acid uptake in muscle $[60,61]$.

Many of the early studies on hormonal regulation of amino acid transport were carried out using intact animals. When interpreting the results of these experiments, one must consider the possibility that exogenously administered hormones may cause the release of other hormones or growth factors that produce secondary effects. The development of in vitro culturing techniques for hormone-sensitive cells and organs has greatly aided the study of the primary effects of hormones on amino acid transport.

From the hundreds of published studies on the hormonal regulation of amino acid transport, using a wide variety of cells and tissues, a few generalizations have emerged. When the hormone-stimulated transport has been assigned to a particular transport system, System A has generally been found to be the hormone-sensitive system. A notable exception is the work of Adamson and Ingbar $[62,63]$ showing that the uptake of System $L$ amino acids by cartilage tissue was increased by thyroid hormones more than the uptake of typical System A substrates. For the liver, three lines of evidence suggest that System $A$ is the only amino acid transport system that responds to hormones. First, the transport system affected by hormones is sodium-dependent, ruling out the involvement of System L [64-67]. Second, the uptake of the System A-specific amino acid MeAIB is stimulated by a wide variety of hormones in isolated hepatocytes, as has also been seen in chick embryo heart cells $[32,68]$ and rat diaphragm (Riggs, T.R., personal cummunication). These observations do not rule out the possibility that sodium-dependent systems other than System A are hormone-sensitive, but do demonstrate the hormone responsiveness of System A as assayed without interference from other transport agencies. Third, the hepatic transport Systems ASC [22], N [22], and L [62,66,69], as measured by the test substrates cysteine, glutamine, and $\mathrm{BCH}$, respectively, all appear to be insensitive to hormones.

Results from several laboratories suggest that the mechanism by which hormones stimulate amino acid transport includes an initial committed step after which the remaining steps can occur in the absence of the hormone. After a short exposure to insulin or glucagon, the continued presence of the hormone is not necessary for the stimulation of transport to occur in isolated rat hepatocytes [70-72]. The increase in AIB uptake in hepatocytes placed in hormone-free medium after a 15-30-min treatment with either insulin or glucagon was about $60 \%$ of that seen when the hormone was present throughout. Even though about $80 \%$ of the cell associated insulin was released during the 60-120 min immediately after removal of the hormone-containing medium [71], the possibility exists that the binding of the hormone to its membrane receptor is the committed step in this process.

The relationship between glucagon receptor occupancy and the degree of amino acid transport stimulation in rat hepatocytes appears to be nonlinear; when only 5-20\% of the glucagon receptors are filled, AIB uptake reaches $50 \%$ of its maximal stimulation. Moreover, $50 \%$ occupancy of the receptors results in almost maximal rates of AIB uptake $[73,74]$. In contrast, studies involving the insulin induction of uptake suggested that insulin receptor occupancy and the degree of amino acid transport stimulation are nearly proportional $[71,74]$. Similar results have been obtained with rat thymocytes $[75,76]$ and chick embryo heart cells [68]. Because the synthesis or activation of amino acid transport carriers may be several steps subsequent to hormone binding, the significance of a lack of correlation between receptor occupancy and stimulation of transport by glucagon is unclear. 
IVA. Effect of down regulation on hormone-stimulated amino acid transport

Prolonged exposure of cells to a hormone often leads to a decrease in the number of receptors for that hormone, a phenomenon referred to as down regulation [77,78]. A decrease in hormone binding should lead to a decrease in hormone-stimulated amino acid transport if the change in binding is within the concentration range affecting transport. For example, amino acid uptake in cultured human fibroblasts is enhanced by treatment with insulin, but after a 4-day exposure to insulin the hormone concentration required to produce a stimulation of AIB uptake equal to that in untreated cells is increased 30-fold [79].

A similar down regulation of insulin-stimulated amino acid transport may operate in the newborn rat diaphragm [80]. Insulin does not stimulate AIB transport in diaphragms from 1-day-old rats, although it does in diaphragms from older rats, even though the basal uptake rate is higher in the tissue from the younger animals. Because the plasma insulin levels of 1-day-old rats are five times those of 5-day-old animals, the decreased responsiveness to the hormone may result from exposure of the diaphragm to high concentrations of insulin. Riggs and co-workers [80] showed that artificially elevating the plasma insulin levels of older rats resulted in a reduction in hormone sensitivity of the diaphragm to a sensitivity similar to that in 1-day-old animals.

Heaton and Gelehrter [81] showed that prolonged exposure of the hepatoma cell line HTC to insulin led to complete hormone resistance as monitored by the stimulation of amino acid transport and the induction of tyrosine aminotransferase. They argued that this effect could not be a result of down regulation of insulin receptors on the basis of two findings. First, the usual loss of receptors during down regulation is generally only about $50-60 \%$ of the total, a reduction insufficient to account for the total lack of response to the higher insulin concentrations tested in these studies. Second, after the hormone-resistant cells were washed to remove the bound insulin, full responsiveness to the hormone was regained within $2 \mathrm{~h}$ [81]. In support of the conclusions of Heaton and Gelehrter [81], Karlsson and colleagues [82] concluded that insulin resistance can result from control at steps subsequent to the hormone-receptor complex.

The effect of growth hormone on AIB uptake in rat diaphragm is an example of the complex relationship between age and the hormonal control of amino acid transport [83-89]. Diaphragms from rats 19 days old or younger showed a stimulation of amino acid uptake following treatment with growth hormone. Transport in diaphragms from older rats did not respond to the hormone, although the hormone sensitivity reappeared when these older animals were hypophysectomized [90,91]. The response of amino acid uptake by diaphragms from 15- to 19-day-old rats was biphasic with respect to the length of exposure to the hormone. A transient stimulation lasting from 1 to $3 \mathrm{~h}$ was observed followed by a period of refractoriness of up to $45 \mathrm{~h}[90,92]$. During this refractory period the diaphragms of the younger rats resembled those of older animals in their insensitivity to growth hormone. This decrease in sensitivity was proposed to result from the action of an inhibitor of amino acid transport [84,92], although no such naturally occurring inhibitor has been isolated. The role of growth hormone receptors in this biphasic response has not yet been determined, although an initial hormonal stimulation of transport followed by a refractory period is consistent with control either by down regulation of growth hormone receptors, or by a post-receptor step as has been proposed for the insulin insensitivity in HTC cells described above.

\section{IVB. Effects of growth factors on amino acid trans- port activity}

Besides by hormones, amino acid transport activities are also affected by several types of growth factors isolated from serum (Table II), including epidermal growth factor [93], fibroblast growth factor [94], platelet-derived growth factor [95], nerve growth factor [96], and multiplicationstimulating activity $[97,98]$. As with hormones, the primary effect of each of these growth factors appears to be a stimulation of System A activity. For nerve growth factor [96] and multiplicationstimulating activity [97] this System A enhancement was characterized by an increase in the $V_{\max }$ of uptake with no change in the $K_{\mathrm{m}}$ of uptake. 
IVC. Role of cyclic AMP and calcium ion in the hormonal regulation of amino acid transport

Conflicting conclusions have been drawn concerning the role of CAMP in the hormonal regulation of System A transport. From earlier studies with liver tissue it was concluded that cAMP mediates the glucagon induction of amino acid transport $[66,99-101]$, based in part on the corre- lation seen between increases in cellular cAMP and increases in transport after glucagon treatment $[102,103]$.

More recent results indicate that increases in cAMP may not be necessary for the stimulation of amino acid transport by glucagon or catecholamines. Treatment of rat hepatocytes with the phosphodiesterase inhibitor 3-isobutyl-1-methylxanthine increased cAMP levels, but did not affect

TABLE III

EFFECT OF HORMONES AND CYCLIC AMP ON AMINO ACID TRANSPORT KINETIC CONSTANTS

\begin{tabular}{|c|c|c|c|}
\hline Tissue or cell type & Effector & Observed effect & Reference \\
\hline \multicolumn{4}{|l|}{ Primary effects on $V_{\max }$} \\
\hline 1. Liver slices & Glucagon & Increased $V_{\max }$ & 173 \\
\hline \multirow[t]{4}{*}{ 2. Hepatocytes } & Glucocorticoids & Increased $V_{\max }$ & 114,115 \\
\hline & Insulin & Increased $V_{\max }$ & 71,72 \\
\hline & Catecholamines & Increased $V_{\max }$ & 114,174 \\
\hline & Glucagon & Increased $V_{\max }$ & 72 \\
\hline \multirow[t]{3}{*}{ 3. Hepatocytes in culture } & Glucagon & Increased $V_{\max }$ & 174,175 \\
\hline & Insulin & Increased $V_{\max }$ & 176 \\
\hline & Glucocorticoids $^{a}$ & Increased $V_{\max }$ & 177 \\
\hline 4. Isolated perfused liver & Growth hormone & $\begin{array}{l}\text { Increased } V_{\max } \\
\text { (with a smaller } \\
\text { increase in } K_{m} \text { ) }\end{array}$ & 165 \\
\hline \multirow{2}{*}{ 5. Hepatoma cells } & Glucocorticoids & Decreased $V_{\max }$ & 119.174 .178 \\
\hline & Insulin ${ }^{b}$ & $\begin{array}{l}\text { Increased } V_{\max } \\
\text { (with a smaller } \\
\text { increase in } K_{\mathrm{m}} \text { ) }\end{array}$ & 118 \\
\hline \multirow[t]{3}{*}{ 6. Thymocytes } & cAMP & Increased $V_{\max }$ & 179 \\
\hline & Glucocorticoids & Decreased $V_{\max }$ & 180 \\
\hline & Insulin & Increased $V_{\max }$ & 75,181 \\
\hline 7. Bone & cAMP & Increased $V_{\max }$ & 182 \\
\hline 8. Lymphocytes & Glucocorticoids & Decreased $V_{\max }$ & 183 \\
\hline \multirow[t]{2}{*}{ 9. Uterus } & Estrogen & Increased $V_{\max }$ & 34,184 \\
\hline & Insulin & Increased $V_{\max }$ & 185 \\
\hline 10. Chick embryo & Insulin & Increased $V_{\max }$ & 73,186 \\
\hline 11. Mammary gland & Insulin & Increased $V_{\max }$ & 133 \\
\hline \multicolumn{4}{|l|}{ Primary effects on $K_{m}$} \\
\hline \multirow[t]{2}{*}{ 1. Hepatocytes in culture } & Glucagon & $\begin{array}{l}\text { Decreased } K_{\mathrm{m}} \\
\text { (with a smaller } \\
\text { increase in } V_{\max } \text { ) }\end{array}$ & 175,177 \\
\hline & Catecholamines & Decreased $K_{\mathrm{m}}$ & 104 \\
\hline 2. Diaphragm & Insulin & Decreased $K_{\mathrm{m}}$ & 125,187 \\
\hline \multirow[t]{2}{*}{ 3. Human fibroblasts } & Glucocorticoids & Decreased $K_{\mathrm{m}}$ & 188 \\
\hline & Insulin & Decreased $K_{\mathrm{m}}$ & 79,93 \\
\hline 4. Lung & Insulin & Decreased $K_{\mathrm{n}}$ & 168 \\
\hline
\end{tabular}

" Effect was only observed after the cells were treated with either glucagon [177] or catecholamine [104]. See text for discussion.

h Effect was only observed after the cells were treated with glucocorticoid [118]. See text for discussion. 
amino acid transport [70]. Pariza and co-workers [104] reported that whereas both epinephrine and isoproterenol increased cellular cAMP, only the epinephrine treatment increased AIB uptake. Furthermore, the relationship between changes in cAMP levels and changes in amino acid uptake in response to hormone treatment in several hepatoma lines also suggests that increases in cAMP are neither necessary nor sufficient to account for the hormonal regulation of transport observed in these cells $[105,106]$.

Using the calcium ionophore A23187, Kelley and colleagues [107] observed that in calcium-depleted cells glucagon did not stimulate AIB uptake, despite a concomitant six- to sevenfold increase in cellular cAMP. Addition of calcium to cells previously depleted of the ion by treatment with A23187 increased both the basal and hormone-stimulated transport [107]. Furthermore, when calcium-depleted hepatocytes were placed in calcium-containing medium, the glucagon stimulation of AIB transport increased with increasing calcium ion concentrations, but the hormone-dependent cAMP production declined [107]. The authors concluded that glucagon induction of hepatic amino acid uptake depends on mobilization of calcium either directly or through changes in cellular cAMP.

\section{IVD. Effects of hormones on the kinetics of amino acid transport}

Many studies of the hormonal stimulation of amino acid uptake have included determination of the kinetic parameters for transport. As discussed elsewhere $[108,109]$, restraint must be exercised in the interpretation of kinetic data based on the enzymological definitions of the kinetic constants $K_{\mathrm{m}}$ and $V_{\text {max }}$. Unless the binding component has been isolated, the $K_{\mathrm{m}}$ calculated for a transport substrate should not be taken as the dissociation constant of the substrate-carrier complex $[108,110]$. Moreover, the multiplicity of transport systems with overlapping specificities in most cell types makes the assignment of $K_{\mathrm{m}}$ values to individual transport routes difficult (see Fig. 4.11 in Ref. 108).

Table III lists the reported effects of hormones on the kinetics of amino acid transport. In most cases, whether the predominant effect of hormone treatment is an increase or decrease in uptake, the change is reflected by a corresponding change in the $V_{\text {max }}$. A few exceptions to this pattern are noted in Table III.

\section{IVE. Effects of glucocorticoids on amino acid trans- port}

The enhancement of the activity of other hormones by glucocorticoids has been termed permissive because the glucocorticoid appears to allow or permit the hormone induction [111]. Potter and co-workers [104] have reported that glucocorticoids acted permissively on the epinephrine stimulation of hepatic AIB uptake, increasing the $V_{\max }$. These investigators also described the permissive effect of glucocorticoids on the stimulation of amino acid transport by glucagon and proposed a model to explain their results [112]. The basic premise of the model is that glucocorticoids maintain a high level of System $A$ in an inactive form. Glucagon is thought to activate this inactive form of the transport system. Because dexamethasone showed the permissive effect with cAMP as well as with glucagon [112], the action of the glucocorticoid was proposed to be at a step subsequent to the glucagon receptor. Potter and colleagues [112] proposed that glucagon may also block the degradation or inactivation of the active transport system.

LeCam and Freychet have also investigated the stimulation of amino acid transport by glucagon $[65,72,73]$ and epinephrine [113,114], but in freshly isolated hepatocytes rather than cultured cells. In contrast to the results of Potter and co-workers, LeCam and Freychet found that for freshly isolated cells: (1) glucocorticoids stimulated AIB uptake in the absence of other hormones [114,115]; (2) the effects of epinephrine [113,114] and the glucocorticoid were additive (that is, the glucocorticoid was not permissive); (3) glucagon [72] and epinephrine [113,114] caused an increase in $V_{\max }$ rather than a decrease in $K_{\mathrm{m}}$; and, (4) isoproterenol stimulated AIB uptake [113,114]. In agreement with the results of Potter, hepatocytes isolated from adrenalectomized rats, whether assayed as freshly isolated suspensions [116] or as primary cultures [117], showed a significantly lower re- 
sponse to glucagon. Interestingly, these cells are also less competent to respond to induction of transport by insulin or amino acid starvation [117].

Gelehrter and colleagues showed that in HTC cells a 2-h dexamethasone treatment caused a decline in AIB uptake, reflected by a $25 \%$ decrease in $V_{\max }[118,119]$, in striking contrast with the increased uptake seen by LeCam and Freychet in freshly isolated hepatocytes [115]. In addition, the continued exposure of HTC cells to dexamethasone for $18 \mathrm{~h}$ resulted in a concomitant increase the in $K_{\mathrm{m}}$ of AIB uptake [118,119]. When HTC cells were exposed to dexamethasone for $18 \mathrm{~h}$ to maximally inhibit transport and then incubated with both dexamethasone and insulin, the uptake of AIB was restored to about $75 \%$ of that in cells not treated with dexamethasone. The insulin-dependent restoration of AIB transport in the dexamethasone-treated cells resulted in a fourfold increase in $V_{\max }$ and a twofold decrease in $K_{\mathrm{m}}$ $[118,119]$. This insulin-dependent restoration of transport may be similar to the permissive effect of glucocorticoids on glucagon-stimulated transport observed by Potter and co-workers [112], described above.

\section{IVF. Possible mechanisms of the hormonal stimula- tion of amino acid transport}

That such a wide variety of hormones stimulate amino acid transport suggests that there are several different routes by which the hormone-mediated stimulation of transport can occur. Possibilities to be considered below include the de novo synthesis of transport carriers, alterations in the membrane potential, and the post-translational conversion of inactive transport carriers to an active form.

\section{IVF-1. De novo synthesis of transport carriers}

The role of de novo protein synthesis in the stimulation of amino acid transport has been studied in several tissues. Most of these studies employed protein synthesis inhibitors such as puromycin or cycloheximide, or blockers of RNA synthesis such as actinomycin $\mathrm{D}$. These inhibitors of macromolecular synthesis usually significantly alter the intracellular pools of amino acids, which in turn may affect System A activity both by trans-inhibition and by adaptive regulation, as dis- cussed above. These changes in intracellular amino acids must be taken into account when macromolecular synthesis inhibitors are used to study transport regulation.

Some of the initial work in this area of research showed that puromycin inhibited the stimulation of protein synthesis by insulin in muscle tissue without blocking its enhancement of amino acid uptake during the first $3 \mathrm{~h}$ of hormone treatment [120-122]. Similar effects of growth hormone on isolated rat diaphragm have been reported $[123,124]$. In contrast, incubation of the muscle tissue with puromycin or actinomycin $D$ for periods longer than $3 \mathrm{~h}$ blocked the insulin-induced transport as well [125]. Incubation with the inhibitors for longer than $3 \mathrm{~h}$ also resulted in a decline in the basal uptake rate of AIB [126-128], enabling Elsas and co-workers to estimate a half-life of the transport system of about $3.5 \mathrm{~h}$. The decay of the basal activity of System A in isolated rat hepatocytes treated with cycloheximide yields an estimated half-life of about $3 \mathrm{~h}$ (Kilberg, M.S., unpublished data). Collectively, the results reported to date are consistent with the proposal that amino acid transport can be enhanced by both protein synthesis-dependent and protein synthesis-independent mechanisms [128]. Using both cycloheximide and actinomycin D, Guidotti and his associates $[129,130]$ concluded that the insulin stimulation of amino acid uptake in chick embryo heart cells involves regulation at the level of translation rather than transcription.

The role of protein synthesis might not be to generate increased amounts of membrane transport components, but rather to alter the levels of factors that regulate transport activity. One possible mechanism by which this regulation could occur is through the degradation of one or more essential components of the transport system. Guidotti and co-workers [129] concluded that in chick embryo heart cells insulin stimulates the synthesis of new proteins necessary for transport activity and also protects the existing transport components from degradation. It has been proposed that the dexamethasone-induced inhibition of System A transport in HTC cells may result from an increased synthesis of a component involved in the degradation of the transport system [131,132]. Similarly, glucagon has been suggested 
to increase hepatic System A activity by slowing the turnover rate of that system [70,112]. The stimulatory and protective action of the hormone on transport may thus result from an increased rate of degradation of a component that inactivates the transport system.

In several tissues the stimulation of amino acid transport has been shown to be independent of protein synthesis, either by an insensitivity to inhibitors or by an induction too rapid to involve de novo protein synthesis. Examples include the insulin effects in mammary tissue [133], diaphragm $[121,124]$, and frog skeletal muscle [134]; the growth hormone-mediated enhancement in diaphragm [123]; a portion of the insulin and glucagon stimulation in rat hepatocytes [135]; and the short-term thyroid effects on System L activity in cartilage tissue $[69,136]$. Edmondson and Lumeng [135] have shown that glucagon stimulates System A transport in freshly isolated rat hepatocytes without a significant lag period, a result obtained by others with isolated perfused liver $[64,99,100,137]$ and hepatocytes in suspension $[65,73]$, but not with primary cultures of hepatocytes ([70], Schwass, D.E. and Christensen, H.N., personal communication). Furthermore, in the studies of Edmondson and Lumeng [135] the initial 15-30-min period of stimulation by glucagon was not altered by treatment with cycloheximide, whereas the increase in transport activity after 30 min was abolished by this inhibitor. Similar results have been obtained after treatment of the cells with cAMP rather than glucagon [138]. These results suggest the existence of two separate phases of hormone stimulation of System A in hepatocytes, an initial period independent of de novo macromolecular synthesis and a second phase dependent on protein synthesis.

\section{IVF-2. Alterations in membrane potential}

There are several possible mechanisms by which amino acid transport activity might be increased independent of protein synthesis. An increase in the magnitude of the transmembrane electrochemical gradient could produce an increase in the transport by System $\mathrm{A}$ as a result of the dependence of this system on the flow of sodium ions. A hormone could hyperpolarize the cell membrane by increasing the membrane permeability to potas- sium ion, by decreasing the membrane permeability to sodium ion, or by increasing the activity of the electrogenic sodium-potassium ATPase [139].

Of the polypeptide hormones that alter the membrane potential, insulin and glucagon have been studied in the greatest detail. Insulin has been reported to hyperpolarize the membrane in several cell types [139-141]. Despite a conflicting report [142], Zierler and Rogus [143] postulated that the rapid insulin-mediated hyperpolarization in adipocytes contributes to the driving force for insulin-stimulated glucose transport. Friedmann and Dambach [144] observed an increase in membrane potential in rat liver from 39.0 to $47.2 \mathrm{mV}$ after glucagon treatment, and similar results have been reported by Graf and Peterson [145]. Addition of insulin resulted in an antagonistic effect such that the glucagon stimulation of membrane potential was abolished.

Edmondson and Lumeng [135] suggested that the glucagon-induced System A uptake is the result of a concomitant increase in membrane potential based on the observed temporal similarities between glucagon-stimulated transport and increased transport caused by an artificially created increase in the membrane potential. Villereal and Cook [146] have implicated cell membrane hyperpolarization in the serum stimulation of amino acid transport in human fibroblasts, which was accompanied by a decrease in $K_{m}$ rather than an increase in the $V_{\max }$ of the transport system. As Villereal and Cook pointed out [146], their results support the 'velocity model' proposed by Geck and Heinz [147], which states that the amino acidsodium ion-carrier ternary complex is the charged form and that the $K_{\mathrm{m}}$ is a measure of the availability of transport sites at the inner and outer surfaces of the membrane.

The difficulty in implicating membrane potential in the mediation of hormonal regulation of transport is in explaining the specificity of the regulation. Although it is not clear that a change in membrane potential would affect every sodium-dependent amino acid transport system equally, presumably a hormone-induced membrane hyperpolarization would cause some increase in uptake by all of the sodium-dependent transport systems, including Systems ASC and N. Neither of these systems has been shown to be 
affected by a variety of hormones $[65,72,129]$. If hyperpolarization of the plasma membrane is to be considered as an explanation for the hormonal regulation of System A activity, the specificity of the response must be adequately explained.

\section{IVF-3. Activation of transport carriers}

Other possible mechanisms for the hormonemediated stimulation of amino acid transport include the activation of inactive carriers or the recruitment of cryptic membrane transport carriers. Potter and associates [112] proposed a model in which glucocorticoids increase the production of an inactive form of the carrier, possibly by regulation at the level of transcription. This step would be dependent on protein synthesis, but would not result in a detectable increase in transport activity. Glucagon is postulated to enhance transport activity by then causing an increased conversion of the inactive carrier to its active form [112]. In theory, this second step could be either dependent or independent of de novo protein synthesis, although most of the induction of transport by glucagon is cycloheximide-sensitive [135].

Protein synthesis-independent stimulation of transport might occur by post-translational modification of a protein, perhaps by the phosphorylation of a protein component of the transport system. Recently, both glucagon- and insulin-stimulated changes in membrane protein phosphorylation were documented for the rat hepatocyte $[148,149]$. Changes in AIB transport by plasma membrane vesicles isolated from mouse fibroblasts have been observed after induction of changes in membrane protein phosphorylation [150]. In these studies, the addition of cAMP-dependent protein kinases resulted in increased phosphorylation of several membrane proteins and a concomitant decrease in AIB uptake [150]. In contrast, the addition of cAMP alone stimulated AIB uptake.

Similarly, much recent interest has centered on the possibility that certain hormones act to stimulate transport by recruiting cryptic transport carriers from internal membranes to the plasma membrane of the cell. In both rat adipocytes $[151,152]$ and rat diaphragm [153] it has been demonstrated that the treatment with insulin results in an increase in the number of glucose transport carriers in the plasma membrane fraction, as assayed by the binding of cytochalasin $\mathrm{B}$, and a corresponding decrease in the number of transport carriers in the microsomal fraction. This translocation of glucose transporters from an intracellular membrane pool has been shown to be reversible [154], and to be blocked by uncouplers of oxidative phosphorylation but not by inhibitors of protein synthesis [155]. A similar recruitment of cryptic transport carriers should be considered as a possible mechanism of the regulation of amino acid transport in rat hepatocytes [156,157]. This type of mechanism will undoubtedly be the focus of much future work on the hormonal regulation of amino acid transport.

\section{Concluding remarks}

It is well established that neutral amino acid transport exhibits both adaptational and hormonal regulation in animal cells. Adaptation of transport activities to meet the nutritional requirements of the cell has been demonstrated in a large number of cell types. Most studies have focused on transport System A, which has been shown to increase in activity in response to complete amino acid starvation and to treatment with hormones including catecholamines, steroids, growth factors, and the polypeptide hormones. Recent work has shown that other transport systems are under regulatory controls. Transport System L has been demonstrated to increase in activity in response to leucine limitation in Chinese hamster ovary cells. This system is also regulated in primary cultures of rat hepatocytes, although this process is not well understood. Finally, System $\mathrm{N}$ has been seen to increase in activity in response to complete amino acid deprivation in normal rat hepatocytes and rat hepatoma cells.

The increased rates of amino acid transport by System A observed after amino acid starvation or hormone treatment have in almost all cases been attributed to increased numbers of membrane transport carriers, reflected by increased $V_{\max }$ values for transport. It has similarly been concluded that the regulation of System $\mathrm{L}$ activity is through changes in the number of transport carriers. Different primary points of control have been postulated for Systems A and L, however. There is substantial evidence from several cell types that 
the major regulatory site for System $A$ is at the level of transcription. In contrast, it has been suggested that for the regulation of System L activity in Chinese hamster ovary cells the primary point of control is at the translational level. For System A, an increase in the number of transport carriers may result primarily from increased rates of transcription of a carrier-specific gene leading to accelerated de novo synthesis of carrier proteins. For System L, on the other hand, an increase in the number of carriers may result primarily from increased rates of translation of carrierspecific mRNA, or perhaps even from the recruitment of existing carriers from intracellular membranes. The recruitment of cryptic transport carriers has been amply demonstrated in the insulin stimulation of glucose transport in rat adipocytes and diaphragm, and may well be involved in the mechanism of the stimulation of amino acid transport by hormones as well.

Genetic approaches should be useful in elucidating the mechanisms of regulation of the amino acid transport systems. Some mutants have been isolated that appear to be defective in the regulation of System L activity in Chinese hamster ovary cells. Additional transport regulatory mutants should yield important information about the normal regulatory mechanisms in animal cells.

\section{Acknowledgements}

This work was supported in part by Grants AM-28374 and AM-31580 from the National Institute of Arthritis, Metabolism, and Digestive Diseases (to M.S.K.), Grant PCM-8203748 from the National Science Foundation (to M.S.K.), and Grant GM-20737 from the National Institute of General Medical Sciences (to D.L.O.).

\section{References}

1 Foster, D.O. and Pardee, A.B. (1969) J. Biol. Chem. 244, $2675-2681$

2 Oxender, D.L., Lee, M. and Cecchini, G. (1977) J. Biol. Chem. 252, 2680-2683

3 Borghetti, A.F., Piedimonte, G., Tramacere, M., Severini, A., Ghiringhelli, P. and Guidotti, G.G. (1980) J. Cell. Physiol. 105, 39-49

4 Moya, F. and Glaser, L. (1980) J. Biol. Chem. 255 , $3258-3260$
5 Parnes, J.R. and Isselbacher, K.J. (1978) Prog. Exp. Tumor Res. 22, 79-122

6 Oxender, D.L. and Christensen, H.N. (1963) J. Biol. Chem. 238, 3686-3699

7 Guidotti, G.G., Borghetti, A.F. and Gazzola, G.C. (1978) Biochim. Biophys. Acta 515, 329-366

8 Christensen, H.N., Liang, M. and Archer, E.G (1967) J. Biol. Chem. 242, 5237-5246

9 Winter, C.G. and Christensen, H.N. (1965) J. Biol. Chem. 240, 3594-3600

10 Eavenson, E. and Christensen, H.N. (1967) J. Biol. Chem. 242, 5386-5396

11 Edmondson, J.W., Lumeng, L. and Li, T.-K. (1979) J. Biol. Chem. 254, 1653-1658

12 Gazzola, G.C., Dall'Asta, V. and Guidotti, G.G. (1980) J. Biol. Chem. 255, 929-936

13 Franchi-Gazzola, R., Gazzola, G.C., Dall'Asta, V. and Guidotti, G.G. (1982) J. Biol. Chem. 257, 9582-9587

14 Shotwell, M.A., Jayme, D.W., Kilberg, M.S. and Oxender, D.L. (1981) J. Biol. Chem. 256, 5244-5247

15 Bass, R., Hedegaard, H.B., Dillehay, L., Moffet, J. and Englesberg, E. (1981) J. Biol. Chem. 256, 10259-10266

16 Vidaver, G.A., Romain, L.F. and Haurowitz, F. (1964) Arch. Biochem. Biophys. 107, 82-87

17 Vidaver, G.A. (1964) Biochemistry 3, 662-667

18 Christensen, H.N. and Handlogten, M.E. (1981) Biochem. Biophys. Res. Commun. 98, 102-107

19 Christensen, H.N. (1975) in Current Topics in Membranes and Transport (Bronner, F. and Kleinzeller, A., eds.), Vol. 6, pp. 227-258, Academic Press, New York

20 Kromphardt, H. (1963) Biochem. Z. 339, 233-254

21 Christensen, H.N. (1964) J. Biol. Chem. 239, 3584-3589

22 Kilberg, M.S., Handlogten, M.E. and Christensen, H.N. (1980) J. Biol. Chem. 255, 4011-4019

23 Handlogten, M.E., Kilberg, M.S. and Christensen, H.N. (1982) J. Biol. Chem. 257, 345-348

24 Kilberg, M.S. (1982) J. Membrane Biol. 69, 1-12

25 Christensen, H.N., Oxender, D.L., Liang, M. and Vatz, K.A. (1965) J. Biol. Chem. 240, 3609-3616

26 Christensen, H.N., Handlogten, M.E., Lam, I., Tager, H.S. and Zand, R. (1969) J. Biol. Chem. 244, 1510-1520

27 Christensen, H.N. (1979) Adv. Enzymol. 49, 41-101

28 Kilberg, M.S., Christensen, H.N. and Handlogten, M.E. (1979) Biochem. Biophys. Res. Commun. 88, 744-751

29 Handlogten, M.E., Garcia-Cañero, R., Lancaster, K.T. and Christensen, H.N. (1981) J. Biol. Chem. 256, 7905-7909

30 Kilberg, M.S., Handlogten, M.E. and Christensen, H.N. (1981) J. Biol. Chem. 256, 3304-3312

31 Bass, R. and Englesberg, E. (1979) In Vitro 15, 829-838

32 LeCam, A. and Freychet, P. (1977) J. Biol. Chem. 252, $148-156$

33 Feneant, M., Moatti, N., Lemonnier, F. and Lemonnier, A. (1981) J. Cell. Physiol. 109, 37-43

34 Riggs, T.R. and Pan, M.W. (1972) Biochem. J. 128, 19-27

35 Gazzola, G.C., Franchi, R., Saibene, V., Ronchi, P. and Guidotti, G.G. (1972) Biochim. Biophys. Acta 266, 407-421

36 Gazzola, G.C., Franchi-Gazzola, R., Ronchi, P. and 
Guidotti, G.G. (1973) Biochim. Biophys. Acta 311, 292-301

37 Guidotti, G.G., Gazzola, G.C., Borghetti, A.F., and Franchi-Gazzola, R. (1975) Biochim. Biophys. Acta 406, 264-279

38 Heaton, J.H. and Gelehrter, T.D. (1977) J. Biol. Chem. $252,2900-2907$

39 Kelley, D.S. and Potter, V.R. (1979) J. Biol. Chem. 254, 6691-6697

40 Dall'Asta, V., Gazzola, G.C., Franchi-Gazzola, R., Maniga, P. and Guidotti, G.G. (1978) Bull. Mol. Biol. Med. 3. 250-259

41 Dall'Asta, V., Gazzola, G.C. and Guidotti, G.G. (1978) Biochim. Biophys. Acta 507, 165-174

42 Smith, C.H., Adcock, E.W., Teasdale, F., Meschia, G. and Battaglia, F.C. (1973) Am. J. Physiol. 224, 558-564

43 Reynolds, R., Rea, C. and Segal, S. (1974) Science 184, $68-69$

44 Reynolds, R.A. and Segal, S. (1976) Biochim. Biophys. Acta 426, 513-525

45 Peck, W.A., Rockwell, L.H. and Lichtman, M.A. (1976) J. Cell. Physiol. 89, 417-428

46 Fehlmann, M., LeCam, A., Kitbagi, P., Rey, J.-F. and Freychet, P. (1979) J. Biol. Chem. 254, 401-407

47 Hayes, M.R. and McGivan, J.D. (1982) Biochem. J. 204. 365-368

48 Kelley, D.S. and Potter, V.R. (1978) J. Biol. Chem. 253. 9009-9017

49 Christopher, C.W., Nishino, H., Schiller, R.M., Isselbacher, K.J. and Kalckar, H. (1979) Proc. Natl. Acad. Sci. U.S.A. 76, 1878-1881

50 Gazzola, G.C., Dall'Asta, V. and Guidotti, G.G. (1981) J. Biol. Chem. 256, 3191-3198

51 Franchi-Gazzola, R., Gazzola, G.C., Ronchi, P., Saibene, V. and Guidotti, G.G. (1973) Biochim. Biophys. Acta 291. 545-556

52 Moore, P.A., Jayme, D.W. and Oxender, D.L. (1977) J. Biol. Chem. 252, 7427-7430

53 Shotwell, M.A., Mattes, P.M., Jayme, D.W. and Oxender, D.L. (1982) J. Biol. Chem. 257, 2974-2980

54 Handlogten, M.E., Weissbach, L. and Kilberg, M.S. (1982) Biochem. Biophys. Res. Commun. 104, 307-313

55 Weissbach, L., Handlogten, M.E., Christensen, H.N. and Kilberg, M.S. (1982) J. Biol. Chem. 257, 12006-12011

56 Giles, R.E., Shimizu, N. and Ruddle, F.H. (1980) Somat. Cell Genet. 6, 667-687

57 Sepúlveda, F.V. and Smith, M.W. (1978) J. Physiol. 282. 73-90

58 Riggs, T.R. (1964) in Actions of Hormones on Molecular Process (Litwack, G., ed.), pp. 1-57, John Wiley and Sons, New York

59 Riggs, T.R. (1970) in Biochemical Action of Hormones (Litwack, G., ed.), pp. 157-208, Academic Press, New York

60 Wool, I.G. (1960) Am. J. Physiol. 199, 715-718

61 Kostyo, J.L. and Schmidt. J.E. (1963) Am. J. Physiol. 204, 1031-1038

62 Adamson, L.F. and Ingbar, S.H. (1967) J. Biol. Chem. 242 , $2646-2652$
63 Adamson, L.F. and Ingbar, S.H. (1967) Endocrinology 81, $1372-1378$

64 Kilberg, M.S. and Neuhaus, O.W. (1977) J. Supramol. Struct. 6, 191-204

65 LeCam, A. and Freychet, P. (1976) Biochem. Biophys. Res. Commun. 72, 893-901

66 Harrison, L.I. and Christensen, H.N. (1971) Biochem. Biophys. Res. Commun. 43, 119-125

67 Flory, W. and Neuhaus, O.W. (1976) Radiat. Res. 68, 138-147

68 Wheeler, F.B., Santora, A.C. III and Elsas, L.J. II (1980) Endocrinology 107, 195-207

69 Adamson, L.F. and Ingbar, S.H. (1967) Endocrinology 81, 1372-1378

70 Pariza, M.W., Butcher, F.R., Kletzien, R.F., Becker, J.E. and Potter, V.R. (1976) Proc. Natl. Acad. Sci. U.S.A. 73. 4511-4515

71 LeCam, A. and Freychet, P. (1978) Diabetologia 15. 117-123

72 Fehlmann, M., LeCam, A. and Freychet, P. (1979) J. Biol. Chem. 254, 10431-10437

73 Freychet, P. and LeCam, A. (1978) in Hepatotrophic Factors, CIBA Foundation Symposium 55, pp. 247-268, Elsevier/North-Holland, Amsterdam

74 Fehlmann, M., Morin, O., Kitbagi, P. and Freychet, P. (1981) Endocrinology 109, 253-261

75 Goldfine, I.D., Gardner, J.D. and Neville, D.M. (1972) J. Biol. Chem. 247, 6919-6926

76 Goldfine, I.D. (1975) Endocrinology 97, 948-954

77 Blackard, W.G., Guzelian, P.S. and Small, M.E. (1978) Endocrinology 103, 548-553

78 Mott, D.M., Howard, B.V. and Bennet, P.H. (1979) J. Biol. Chem. 245, 8762-8767

79 Martin, M.S. and Pohl, S.L. (1979) J. Biol. Chem. 254, 9976-9978

80 Riggs, T.R., Wise, H.D. and Motz, K.L. (1978) Am. J. Physiol. 235, E304-E310

81 Heaton, J.H. and Gelehrter, T.D. (1980) Biochem. Biophys. Res. Commun. 92, 795-802

82 Karlsson, F.A., Van Obberghen, E., Grunfeld, C. and Kahn, C.R. (1979) Proc. natl. Acad. Sci. U.S. 76, 809-813

83 Hjalmarson, A. (1968) Acta Endocrinol. Suppl. 126, 1-17

84 Hjalmarson, A. (1968) Acta Endocrinol. Suppl. bX 19-35

85 Hjalmarson, A. (1968) Acta Endocrinol. Suppl. 126, 37-48

86 Albertsson-Wikland, K. and Isaksson, O. (1978) Endocrinology 102, 1445-1451

87 Isaksson, O., Nutting, D.F., Kostyo, J.L. and Reagan. C.R. (1978) Endocrinology 102, 1420-1428

88 Albertsson-Wikland, K., Eden, S. and Isaksson, O. (1980) Endocrinology 106,291-297

89 Albertsson-Wikland, K., Eden, S., Ahren, K. and Isaksson, O. (1980) Endocrinology 106, 298-305

90 Hjalmarson, A. and Ahren, K. (1967) Acta Endocrinol. 56, 347-358

91 Nutting, D.F. (1967) Endocrinology 98, 1273-1283

92 Nutting, D.F. and Coats, L.J. (1977) proc. Soc. Exp. Biol. Med. 156, 446-451

93 Hollenberg, M.D. and Cuatrecasas, P. (1975) J. Biol. Chem. 250, 3845-3853 
94 Quinlan, D.C. and Hochstadt, J. (1977) J. Cell. Physiol. 93, 237-246

95 Owen, A.J. III, Geyer, R.P. and Antoniades, H.N. (1982) Proc. Natl. Acad. Sci. U.S.A. 79, 3203-3207

96 McGuire, J.C. and Greene, L.A. (1979) J. Biol. Chem. 254, 3362-3367

97 Derr, J.T. and Smith, G.L. (1980) J. Cell. Physiol. 102, $55-62$

98 Heaton, J.H., Schilling, E.E., Gelehrter, T.D., Rechler, M.M., Spencer, C.J. and Nissley, S.P. (1980) Biochim. Biophys. Acta 632, 192-203

99 Mallette, L.E., Exton, J.H. and Park, C.R. (1969) J. Biol. Chem. 244, 5724-5728

100 Chambers, J.W., Georg, R.H. and Bass, A.D. (1970) Endocrinology $87,366-370$

101 Tews, J.K., Woodcock, N.A. and Harper, A.E. (1970) J. Biol. Chem. 245, 3026-3032

102 Scott, D.F., Reynolds, R.D., Pitot, H.C. and Potter, V.R. (1970) Life Sci. 9, 1133-1140

103 Butcher, F.R., Scott, D.F. and Potter, V.R. (1971) FEBS Lett. 13, 114-116

104 Pariza, M.W., Butcher, F.R., Becker, J.E. and Potter, V.R. (1977) Proc. Natl. Acad. Sci. U.S.A. 74, 234-237

105 Scott, D.F., Butcher, F.R., Potter, V.R. and Morris, H.P. (1972) Cancer Res. 32, 2127-2134

106 Butcher, F.R., Scott, D.F., Potter, V.R. and Morris, H.P. (1972) Cancer Res. 32, 2135-2140

107 Kelley, D.S., Evanson, T. and Potter, V.R. (1980) Proc. Natl. Acad. Sci. U.S.A. 77, 5953-5957

108 Christensen, H.N. (1975) Biological Transport, 2nd ed., W.A. Benjamin, Reading, MS

109 Christensen, H.N. (1976) J. Cell. Physiol. 89, 603-604

110 Thomas, E.L. and Christensen, H.N. (1971) J. Biol. Chem. 246, 1682-1688

111 Kletzien, R.F., Pariza, M.W., Becker, J.E. and Potter, V.R. (1975) Nature 256, 46-47

112 Pariza, M.W., Kletzien, R.F., Butcher, F.R. and Potter, V.R. (1976) Adv. Enz. Reg. 14, 103-115

113 LeCam, A. and Freychet, P. (1978) Endocrinology 102, $379-385$

114 Canivet, B., Fehlmann, M. and Freychet, P. (1980) Mol. Cell. Endocrin. 19, 253-261

115 LeCam, A. and Freychet, P. (1977) Mol. Cell. Endocrin. 9, 205-214

116 Dolais-Kitbagi, J., Faure, T. and LeCam, A. (1980) Mol. Cell. Endocrin. 24, 315-323

117 Kilberg, M.S., Vida, T.A. and Barbre, E.F. (1983) J. Cell. Physiol. 114, 45-52

118 Risser, W.L. and Gelehrter, T.D. (1973) J. Biol. Chem 247, 6727-6931

119 Gelehrter, T.D., Risser, W.L. and Reichberg, S.B. (1975) in Gene Expression an Carcinogenesis in Cultured Liver (Gerschenson, L.E. and Thompson, E.B., eds.), pp. 24-45, Academic Press, New York

120 Wool, I.G. and Moyer, A.N. (1964) Biochim. Biophys. Acta 91, 248-256

121 Wool, I.G., Castles, J.J. and Moyer, A.N. (1965) Biochim. Biophys. Acta 107, 333-345
122 Fritz, G.R. and Knobil, E. (1963) Nature 200, 682

123 Knobil, E. (1966) Physiologist 9, 25-44

124 Kostyo, J.L. (1968) Ann. N.Y. Acad. Sci. 148, 389-407

125 Elsas, L.J., Albrecht, I. and Rosenberg, L.E. (1968) J. Biol. Chem. 243, 1846-1853

126 Elsas, L.J., Albrecht, I., Kochne, W. and Rosenberg, L.E. (1967) Nature 214, 916-917

127 Manchester, K.L. (1967) Nature 216, 394-395

128 Elsas, L.J., MacDonell, R.C. Jr. and Rosenberg, L.E. (1968) J. Biol. Chem. 246, 6452-6459

129 Guidotti, G.G., Franchi-Gazzola, R., Gazzola, G.C. and Ronchi, P. (1974) Biochim. Biophys. Acta 356, 219-230

130 Guidotti, G.G., Gazzola, G.C. and Franchi-Gazzola, R. (1974) Adv. Cytopharmacol. 2, 155-162

131 Makman, M.H., Dovrkin, B. and White, A. (1971) Proc. Natl. Acad. Sci. U.S. 68, 1269-1273

132 Gelehrter, T.D. (1979) in Glucocorticoid Hormone Action (Baxter, J.D. and Rousseau, G.G., eds.), pp. 561-574, Springer-Verlag, Heidelberg

133 Lobitz, C.J. and Neville, M.C. (1977) J. Supramol. Struct. $6,355-362$

134 Grinstein, S. and Erligj, D. (1977) J. Membrane Biol. 35, 9-28

135 Edmondson, J.W. and Lumeng, L. (1980) Biochem. Biophys. Res. Commun. 96, 61-68

136 Adamson, L.F. (1970) Biochim. Biophys. Acta 201, 446-452

137 Chambers, J.W., Georg, R.H. and Bass, A.D. (1968) Endocrinology 87, 366-370

138 McGivan, J.D., Ramsell, J.C. and Lacey, J.H. (1981) Biochim. Biophys. Acta 644, 295-304

139 Zierler, K. and Rogus, E.M. (1981) Fed. Proc. 40, 121-124

140 Lantz, R.C., Elsas, L.J. and DeHaan, R.L. (1980) Proc. Natl. Acad. Sci. U.S. 77, 3062-3066

141 Czech, M.P. (1977) Annu. Rev. Biochem. 46, 359-384

142 Stark, R.J., Read, P.D. and O'Doherty, J. (1980) Diabetes $29,1040-1043$

143 Zierler, K. and Rogus, E.M. (1980) Am. J. Physiol. 239, E21-E29

144 Friedmann, N. and Dambach. G. (1980) Biochim. Biophys. Acta 596, 180-185

145 Graf, J. and Petersen, O.H. (1978) J. Physiol. 284, 105-126

146 Villereal, M.L. and Cook, J.S. (1978) J. Biol. Chem. 253, 8257-8262

147 Geck, P. and Heinz, E. (1976) Biochim. Biophys. Acta 443, $49-53$

148 LeCam, A. (1982) J. Biol. Chem. 257, 8376-8385

149 LeCam, A., Auberger, P. and Samson, M. (1982) Biochem. Biophys. Res. Commun. 106, 1062-1070

150 Nilsen-Hamilton, M. and Hamilton, R.T. (1979) Biochim. Biophys. Acta 588, 322-331

151 Cushman, S.W. and Wardzala, L.J. (1980) J. Biol. Chem. $255,4758-4762$

152 Suzuki, K. and Kono, T. (1980) Proc. Natl. Acad. Sci. U.S.A. 77, 2542-2545

153 Wardzala, L.J. and Jeanrenaud, B. (1981) J. Biol. Chem. 256, 7090-7093

154 Karnieli, E., Zarnowski, M.J., Hissin, P.J., Simpson, I.A., 
Salans, L.B. and Cushman, S.W. (1981) J. Biol. Chem. 256 , 4772-4777

155 Kono, T., Suzuki, K., Dansey, L.E., Robinson, F.W. and Blevins, T.L. (1981) J. Biol. Chem. 256, 6400-6407

156 Prentki, M., Crettaz, M. and Jeanrenaud, B. (1981) J. Biol. Chem. 256, 4336-4340

157 Mak, W.W. and Pitot, H.C. (1981) Biochem. Biophys. Res. Commun. 98, 203-210

158 Touabi, M. and Jeanrenaud, B. (1969) Biochim. Biophys. Acta $173,128-140$

159 Peterkofsky, B. and Prather, W. (1979) Arch. Biochem. Biophys. 192, 500-511

160 Weiss, I.W., Morgan, K. and Phang, J.M. (1972) J. Biol. Chem. 247, 760-764

161 Fuller, R.W. and Baker, J.C. (1975) FEBS Lett. 53, 8-9

162 Santora, A.C. III, Wheeler, F.B., DeHaan, R.L. and Elsas. L.J. (1979) Endocrinology 104, 1059-1068

163 Bonney, R.J. and Maley, F. (1975) in Gene Expression and Carcinogenesis in Cultured Liver (Gerschenson, L.E. and Thompson, E.B., eds.), pp. 24-45, Academic Press, New York

164 Chambers, J.W., Georg, R.H. and Bass, A.D. (1965) Mol. Pharmacol. 1, 66-67

165 Jefferson, L.S., Schworer, C.M. and Tolman, E.L. (1975) J. Biol. Chem. 250, 197-204

166 Daniel, P.M., Love, E.R. and Pratt, O.E. (1979) J. Physiol. 291, 41P

167 Hissin, P.J. and Hilf, R. (1978) Cancer Res. 38, 3646-3655

168 Gregorio, C.A. and Massaro, D. (1977) J. Appl. Physiol. 42, 216-220

169 Murota, S. and Kawamura, M. (1977) Biochem. Biophys. Res. Commun. 76, 995-1001

170 Hollenberg, M.D. and Fryklund, L. (1977) Life Sci. 21, 943-950
171 Syme, G. and Levin, R.J. (1977) Biochim. Biophys. Acta $464,620-628$

172 Kumar, S. and Alli, P. (1978) Fed. Proc. 37, 1397

173 Tews, J.K., Woodcock-Colosi, N. and Harper, A.E. (1975) Life Sci. 16, 739-750

174 Ayala, E. and Canonico, P.G. (1975) Proc. Exp. Biol. Med. $149,1019-1022$

175 Kelley, D.S., Campbell, H.A. and Potter, V.R. (1982) J. Cell. Physiol. 112, 67-75

176 Kletzien, R.F., Pariza, M.W., Becker, J.E., Potter, V.R and Butcher, F.R. (1976) J. Biol. Chem. 251, 3014-3020

177 Kletzien, R.F., Pariza, M.W., Becker, J.E. and Potter, V.R. (1976) J. Cell. Physiol. 89, 641-646

178 Reichberg, S.B. and Gelehrter, T.D. (1980) J. Biol. Chem. $255,5708-5714$

179 Goldfine, I.D. and Sherline, P. (1972) J. Biol. Chem. 247, $6727-6731$

180 Baran, D.T., Peck, W.A., Frengley, P.A. and Lichtman, M.A. (1973) Biochim. Biophys. Acta 307, 627-639

181 Kwock, L. and Wallach, D.F.H. (1974) Biochim. Biophys. Acta $352,135-145$

182 Phang, J.M. and Downing, S.J. (1973) Am. J. Physiol. 224, 191-196

183 Baran, D.T., Lichtman, M.A. and Peck, W.A. (1972) J. Clin. Invest. 51, 2181-2189

184 Riggs, T.R., Pan, M.W. and Feng, H.W. (1968) Biochim. Biophys. Acta 150, 92-103

185 Mohri, T., Ketagawa, H. and Riggs, T.R. (1974) Biochim. Biophys. Acta 363, 249-260

186 Elsas, L.J., Wheeler, F.B., Danner, D.J. and DeHaan, R.L. (1975) J. Biol. Chem. 250, 9381-9390

187 Akedo, H. and Christensen, H.N. (1962) J. Biol. Chem. $237,118-122$

188 Hollenberg, M.D. (1977) Mol. Pharmacol. 13, 150-160 